\title{
Editor's Introduction: Imagination, Interpretation and Science
}

\section{T. Nichols ${ }^{1}$}

Published online: 13 August 2020

(C) Springer Science+Business Media, LLC, part of Springer Nature 2020

At the time of its founding, in 1965, The American Sociologist, under inaugural editor Talcott Parsons, began to examine the past, present and future of sociology as an organized field of learning. All members of the American Sociological Association received a copy of the journal as a benefit of their dues. The perspective of the journal, however, was generally limited to the state of sociology in the United States. Since that time, the journal's outlook has broadened to consider sociology around the world, though not in a fully comprehensive or systematic way. Under my editorship, sets of articles have been published on sociology in Canada, in Japan and in France.

But the present issue, on the theme of the essayist tradition in Brazil, is the first to offer scholarly contributions on the field in Latin America. Special thanks are due to Professors Veridiana Cordeiro and Hugo Neri, who solicited papers, communicated with authors, helped to find peer reviewers and did much to keep the project on schedule. I also very much appreciate the individual contributions and the willingness of authors to invest time and effort in revisions based on reviews and editorial guidance. This collaboration has been a pleasure.

There is a significant literature on the process by which sociology became, or perhaps failed to become, a science comparable to other social and natural sciences. One influential exemplar was the two-volume study by Howard P. Becker and Harry Elmer Barnes, Social Thought from Lore to Science. Patricia Lengermann and Gillian Niebrugge provided a feminist perspective in their survey of The Women Founders. Jonathan Turner and Stephen Turner offered a more skeptical and critical view in The Impossible Science. More recently, Stephen Turner brought out a study of American Sociology: From Pre-Scientific to Post-Normal. And just a year ago Colin Campbell raised the question, Has Sociology Progressed?

These and other similar works recognized contributions by early figures who were not professional academics or who did not have formal training in the field of sociology. Harriet Martineau, who translated and edited sociological writings by Comte, and who carried out an ethnographic study of "manners and morals" in the

L. T. Nichols

ltnichols@retiree.wvu.edu

1 West Virginia University, Morgantown, WV, USA 
U.S., was known primarily as a professional writer. Jane Addams and members of her Hull House circle, who carried out influential studies of urban life in Chicago, generally did not have degrees in sociology. This is also true of W. E. B. DuBois, though he had earned a Ph.D. in history from Harvard. Robert E. Park, the leading figure in the "classic Chicago school" of the 1920s and 1930s, also held a Harvard Ph.D., in philosophy. Even Talcott Parsons, who sought to provide in 1937 what Charles Camic characterized as a "charter for sociology" in The Structure of Social Action, had a degree in economics, rather than sociology. Robert Merton has described Parsons as "perhaps the last autodidact" in sociology. But even after World War II there were occasional cases. For instance, David Riesman, who along with Nathan Glazer and Reuel Denney wrote the best-selling work, The Lonely Crowd, had majored in English and taken a degree at Harvard Law.

The contributions of non-professionals and non-specialists have likewise been recognized in the history of the natural sciences and technology. There, talented amateurs made valuable early discoveries in fields such as astronomy. Benjamin Franklin, with his homemade experiments on electricity, is another famous example. The inventor of a method to measure longitude at sea, John Harrison, was a clockmaker in eighteenth-century England. The Wright brothers, inventors of the first successful aircraft, sold and repaired bicycles. In the 1940s, popular movie star Heddy Lamarr and the composer George Antheil patented a design for frequency-hopping, spread spectrum technology that earned them a place in the National Inventors Hall of Fame.

All of this is related to the papers in this issue, which examine the work of Brazilian "essayists" in the late nineteenth and early twentieth centuries, including such especially prominent figures as Sergio Buarque de Holanda, Gilberto Freyre, and Caio Prado, Jr. These were cultured people, sometimes from privileged backgrounds, and relatively well educated. They cared deeply about the state of their society, as well as its history and prospective future, and they offered bold interpretive writings. In a sense, they prepared the way for the emergence of a science of sociology in Brazil, although as some of the articles point out, there is a tension between the earlier essayists and later sociological scientists such as Florestan Fernandes. Although men dominated in the production of essays, there were also influential women such as Gilda de Mello e Souza and Victoria Ocampo (in Argentina), who broke out of traditional gender roles.

"Pre-scientific" works sometimes suffer from the absence of a conceptual framework, a lack of methodological sophistication and inadequate grounding in relevant empirical evidence. Sometimes referred to as "arm-chair sociology," they may be difficult to distinguish from mere opinion, or perhaps ideology. But "scientific" works sometimes run the risk of being excessively mechanical and ritualistic. While the former may be overly free in their speculations, the latter may be timid and data bound. The best works, as Pitirim Sorokin often emphasized, seem to be characterized by a creative quality that goes beyond the mere summary of data to an insightful understanding that is ultimately grounded in intuition. Some feel that DuBois achieved this in his somewhat poetic idea of "the veil" in The Souls of Black Folk.

Albert Einstein famously remarked that the most important quality in science is imagination. Einstein pictured himself traveling through the physical universe on a beam of light - a procedure that would not be taught in any doctoral program in physics. Many sociologists still draw inspiration from C. Wright Mills's 1959 work, The Sociological Imagination, on seeing connections between the micro biographical 
and the macro historical levels. More recently, Andrew Abbott (as "Barbara Celarent") posed the issue cross-culturally in Varieties of Social Imagination, a work that made a deep impression on Professors Cordeiro and Neri, as they report in their "Foreword."

While many would laud the role of intuition in scientific discovery, some would raise concerns as to whether intuition can confirm knowledge or determine its veracity. Thus, if an essay seems plausible and offers a way of understanding what was previously puzzling, does that mean that it is "true"? Or is it true only for "those who believe," who have what psychologist-philosopher William James called "the will to believe"? Is knowledge ultimately a matter of faith, even within scientific communities that are presumably organized on the basis of systematic doubt and methodological rigor? If so, how do we distinguish valid knowledge from mere prejudice? Such questions are well worth reflecting upon, even if there are no final answers.

There is also the related issue of knowledge "from outside" or "from within." In early modern science in Europe, which reacted against religious orthodoxy, the emphasis was clearly on external knowledge produced by disciplined practitioners of scientific method who bracketed their personal opinions. But there was always a parallel tradition of internal ways of knowing, especially in philosophy. As social sciences emerged, some leading figures emphasized interiority, perhaps most famously in psychological "introspection" that dealt with meanings and emotions, which are difficult to observe. Economics likewise focused on the states of mind and value commitments of decision makers until at least the 1930s, when the field became intensely mathematical.

More recently, in many academic fields, knowledge has been linked to membership in particular groups, sometimes in conjunction with "identity politics." In this approach, only insiders can truly understand the phenomenological "life world" that is shared by participants. This is sometimes expressed in terms of "standpoint epistemology." Feminists have perhaps been its most widely recognized advocates, with their concepts of "feminist ontology" and "feminist method." Membership-based knowledge has also been a prominent issue in the literature on ethnography and community studies, and it is cited in proposals for "participatory research." There are other variants based on the worlds of social class, nationalism and religious faith. Age has also been presented as an insider-outsider boundary, as in the "generation gap" controversy of the 1960s. And, of course, there are numerous "intersectional" combinations of membership criteria, as in the "black feminism" of Patricia Hill Collins. Membership-based epistemology problematizes the relation between insiders and outsiders, suggesting that nonmembers can never really understand, or else can understand only via what might be called "translations" by insiders who mediate between otherwise separate social worlds.

The Brazilian essayist tradition clearly follows the model of "insider" or "membership-based" knowledge. Thus, in order to understand Brazil, one must have experienced its distinctive life and culture, its mixture of races and ethnicities, with an awareness of its history and colonial subjugation, the aspirations of its people and its internal conflicts. Such experiential grounding provides the competence to speak, and to interpret, even without formal scientific training. This, at least, is the underlying assumption.

In order to carry on as a "living tradition and an ever-new beginning," sociology needs large ideas comparable to those of the Brazilian essayists. It needs fresh, inspiring, insightful and constructive ideas in order to avoid fact-oriented superficiality, 
methodological ritualism and stale, predictable ideological formulas. So perhaps it is the imaginative creativity of the essayists, rooted in a concern for the common good, that is the best lesson to be drawn from our thematic set of articles.

Publisher's Note Springer Nature remains neutral with regard to jurisdictional claims in published maps and institutional affiliations. 